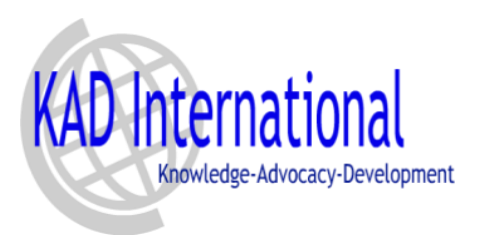

Copyright (C) 2014 by KAD International

All rights reserved.

Published in the Ghana

http://kadint.net/our-journal.html

\title{
Positive Image of the USSR and Soviet Characters in American Films in 1943-1945
}

\author{
Alexander Fedorov
}

Rostov State University of Economics, Russian Federation

Prof. Dr. (Pedagogy)

E-mail: mediashkola@rambler.ru

\begin{abstract}
In the article the author performs a hermeneutic analysis of cultural context, i.e. investigation of media texts interpretation, cultural and historical factors influencing the views of the agency / author of a media text and the audience, on specific examples of positive image of the USSR and soviet characters in American films in 1943-1945. The author bears in mind that the hermeneutic analysis of a media text comprehension involves a comparison with a historical, cultural tradition and reality; insight into its logic; comparison of media images in historical and cultural contexts combined with the historical, hermeneutical analyses of the structural, plot, ethical, ideological and iconographic / visual analyses of media stereotypes and media text characters. The analysis of these media texts, in the author's opinion, is especially important for media education of future historians, culture experts, art critics, social scientists, philologists, psychologists and teachers.

Keywords: Russian Image; Film Studies; Media Text; Hermeneutic Analysis; Russia; USA; Media Education; Media Literacy; Media Competence; Movie.

\section{Introduction}

In one of my previous books [Fedorov, 2010] I analysed a rather adverse image of the USSR on the western screen in the epoch of ideological confrontation (1946-1991). However there was a short period in the history of Soviet-American relations, when the image of the Soviet country and its citizens on the American screen was positively charged: 1943-1945, the time when Americans and Russian were allies in the WWII.

\section{Materials and Methods}

During that period of time 7 feature films (and several documentaries as well) were produced in the USA, which main characters were "good" Soviets: Mission to Moscow (1943), The boy from Stalingrad (1943), North Star (1943), Three Russian Girls (1943), Song of Russia (1944), Days of Glory (1944), Counter-Attack (1945). Meanwhile majority of these films were directed by prominent directors, an Oscar winner, the author of a legendary Casablanca (1942) Michael Curtiz (1988-1962) and the author of the drama All Quiet on the Western Front (1930) Lewis Milestone (1895-1980) among them. Moreover, such Hollywood actors as R. Taylor and G. Peck starred in some of them. Soviet cinema only answered this unprecedented "film-goodwill" gesture with documentary films, positively evaluating American and British participation in the fight against Nazi Germany. Feature cinema industry of the USSR didn't take part in that, due to the inevitable need of presenting the lifestyle in allied countries.

The first step in the series of oversees allied friendship was Mission to Moscow, premiered in the USA at the end of April, and in the USSR - on the 26th of July of 1943. The only European country that ventured to screen this pro-Soviet film in the war years, was neutral Sweden, where in November and December of 1944 (when the outcome of the war was already clear) were screened two American films about the USSR - Mission to Moscow and Days of Glory.
\end{abstract}


Mission to Moscow was somewhat an order of the state, a screen adaptation of the book by an ex-ambassador to the USSR (1936-1938) Joseph E. Davies. However while the book was rather positive about presenting events in the USSR and Stalin's policy on the whole, its screen version was only concentrated on the rosy view of the Soviet lifestyle. Not only were the Soviet achievements in industry and agriculture, but also "demonstrative" lawsuits against enemies of the state shown in Mission to Moscow in a really advantageous way for Kremlin. The screen features a bright, prosperous Moscow. The film also justifies the USSR's attack against Finland in 1939, as well as the August 1939 Pact between Germany and the USSR.

This is why of all pro-Soviet Hollywood films it was Mission to Moscow that was honoured to be shown on Soviet screens. It is worth noting that later on it was for such a clear positive support of the Soviet regime that the authors of the film were accused of during the 1947 House UnAmerican Activities Committee, investigating anti-American activity.

Meanwhile the authors of Mission to Moscow flattered the Soviet authority. The minister of foreign affairs M. Litvinov proves his point to the American ambassador Joseph E. Davies that "there is no security for any of us as long as there is no security for all". M. Kalinin jokingly mentions that "his favourite sin is American cigarettes". V. Molotov, Marshal Timoshenko and prosecutor Vyshinsky are portrayed favourable as well. J. Davies in one of the final episodes of the film calls Stalin as "the great builder for the benefit of mankind"...

A considerable part of the screen time is dedicated to the travel of J. Davies across the USSR: Kharkiv, Odessa, Donbas, Dneproges, Baku..."Tractors, coal, electricity, steel, amazing, astonishing, wonderful!" Mr. Davies is speechless. "I can't find another example in the history of mankind, when so much was done in such a short period of time", - Davies says to Molotov. "What great people! Patriots! And women! They work in the mines - because they have equal rights with men, they drive trains, assemble tractors. The work is humming, tractors are being assembled, but in case of the war, in case of the military actions, the same plant will produce tanks. Amazing, astonishing, wonderful! " [Lemkhin, 2012].

Inherently, Mission to Moscow was a kind of a diplomatic tool for the USA, the tool that was supposed to bribe a military ally.

Certainly, the screening of Mission to Moscow (which by the way was a box-office failure in the USA) raised not only favourable reviews but also critical ones in American press. Bennet [Bennet, 2001] cites numerous opinions of that kind.

On the other hand, judging by the reviews in Soviet papers such as Komsomolskaya Pravda, Vechernyaya Moskva, Izvestia, this film was an act of friendly gratitude of the USA to the Soviet Union and Red Army.

However for American policy the fact that by demonstrating a high standard of living in the USA, "Hollywood started to compete with the communist party for hearts and minds of the Soviet audience... Mission to Moscow became a weapon of "soft power", its public release opened the way to previously banned in the Soviet Union legions of Hollywood films" [Bennet, 2001].

Another pro-Soviet Hollywood film of 1943 was The North Star (it was shown in Sweden in March 1945). June 1941. A quiet Soviet village is attached by Nazi aviation. Soon it is occupied by its army. A Nazi doctor (played by legendary Erich Oswald Stroheim) decided to use local children for blood transfusion for German soldiers. But Soviet men able to hold weapon in hands, become partisans and do everything to hinder him.

Indeed, a rural life is depicted on the screen in a grotesque way, but on the whole the story is told with a great deal of compassion and sympathy for the USSR and Soviet people. Therefore, no wonder that after the end of the war, both Mission to Moscow and The North Star were declared as pro-Soviet propaganda by the House Un-American Activities Committee.

A sympathetic pathos was characteristic of the film The Boy from Stalingrad (1943) where country teenagers start the fight against occupants, along the way saving Tommy, the son of the British consul, who lost his parents during the evacuation attempt from Stalingrad, attacked by the Nazis.

The main stake of the pro-Soviet Hollywood in 1944 was a melodrama Song of Russia. The leading male role of an American band-master was played by a famous American actor Robert Taylor (1911-1969) who had to explain himself and find excuses for this work in front of the same Committee after the war. 
This film turned out to be a fatal one for him. According to the plot, Taylor's character comes to Moscow on tour in 1941 and falls in love with a pretty Russian girl Nadya, a talented country pianist. As it sometimes happens on film sets, Taylor (who was married to an American star Barbara Stanwyck at the time) really had an affair with a charming actress who played Nadya Susan Peters (1921-1952). However unlike the film characters, actors didn't reach the happy ending: not being able to divorce, Taylor went to serve in the army. S. Peters married another man, in 1945 was wounded accidentally during the hunting, paralyzed and died in 1952.

Like Mission to Moscow and The North Star, Song of Russia was also full of grotesque idealization of life in the USSR. Having graduated from the country music school, Nadya comes to Moscow to see the concert of an American conductor, and impresses him with her piano performance. Everyone in her village is keen on classical music! Mikhail Chekhov who played Nadya's father, a tractor driver and a musician, did not manage to make this melodramatic popular print more realistic...

In a very favorable to the USSR melodrama Days of Glory (1944) the leading male role was played by a Hollywood star Gregory Peck (1916-2003). His brave character is the leader of partisans. He hides in the woods and commits acts of sabotage against Nazis. Naturally all women partisans, one played by a Russian ballet dancer Tamara Tumanova, were in love with such a handsome and courageous man.

Almost on the eve of the Nazi's Germany defeat - in the end of April, 1945- American screens featured another pro-Soviet film - a drama Counter-Attack, where Soviet and Nazi soldiers find themselves in one vault.

\section{Conclusion}

Accessibility of the majority of the above mentioned films due to their DVD and Internet releases, makes it possible to analyse media stereotypes of the positive image of the USSR and Soviet characters in American films of 1943-1945 at the media literacy classes with students according to the following scheme.

Structure of the stereotypes of the positive image of the USSR and Soviet characters in American films of 1943-1945

Structure of the stereotypes of drama genre films (as exemplified in Mission to Moscow, the

Historical period, location: relatively short period of time between the 1930s-1940s; the USSR, the USA, Germany, some other countries.

Environment, everyday objects: impressive Soviet plants and electrical stations, war parades and diplomatic receptions, rather decent houses and possessions of Soviet characters, comfortable housing and possessions of western characters.

Means of representation: quasi-realistic, only advantageous portrayal of Soviet lifestyle.

Characters, their values, ideas; clothes, appearance, lexis, body language:

- good characters - Americans who believe in democracy, and find themselves in the USSR (the Ambassador and his family in the first place), Soviet state leaders (Stalin, Kalinin, Molotov) and common Russian people, aimed at creating the new society, patriotism and struggle for peace. They look nice, speak with pathos, Soviet women look pretty, they are well-dressed and even go shopping for perfume;

- villains - have anti-humane, military ideas (Nazis), traitors and terrorists (arrested Trotsky's supporters and other enemies of Stalin regime).

The characters are divided by both social and material status. Villains are on the whole portrayed as unpleasant people with appalling voice timbre. However some of the Soviet negative characters (for example, Tukhachevsky) at first look rather presentably.

A crucial change in characters' life: villains are going to implement their anti-humane ideas (Nazis are preparing to attack the USSR, and oppositionists - Trotsky's supporters are plotting a scheme).

A problem occurred: life of good characters as well as life of whole nations and countries are in danger.

Searching for the problem solution: struggle of good characters with bad ones (American ambassador and good Soviet state leaders are doing their best to prevent the war by diplomatic means; open for foreign visitors Soviet court convicts Trotsky's followers and other plotters). 
Solving the problem: condemning villains; armed struggle of the USSR troops against Nazi army; anti-Nazi alliance between the USSR and the USA.

Structure of stereotypes of melodrama genre films

(as exemplified in Song of Russia, the USA, 1944) USA.

Historical period, location: short period of time between the 1941 and 1944; the USSR, the

Environment, everyday objects: modest but decent dwelling and possessions of Soviet characters, even rural ones (although the set where the main female character lives looks rather unusual for the Russian eye as it contains elements of American architecture); spacious concert halls.

Means of representation: quasi-realistic, only favourable view of Soviet lifestyle.

Characters, their values, ideas; clothes, appearance, lexis, body language: male and female characters have contrasting ideological and social status. He is a famous American conductor. She is a beautiful country girl, brilliantly playing the piano. All characters in the film are only shown in positive light. Main characters look slim, attractive, they're dressed in good taste. They are emotional, their gestures are sometimes expressive, lexicon is rich.

A crucial change in characters' life: the meeting of the man and the woman, love between them.

A problem occurred: ideological and social misalliance, start of the war, temporary separation of characters.

Searching for the problem solution: characters overcome ideological and social barriers between them.

Solving the problem: the wedding/love harmony (noticeably, the two main characters are getting married in Russian orthodox church), the final reunion after the separation, caused by the war, mutual decision to move to the USA in order to give concerts together, performing Russian classical music.

Structure of the stereotypes of comedy genre films (as exemplified in Three Russian Girls, the USA, 1943)

Historical period, location: short period of time from 1941 to 1943; the USSR.

Environment, everyday objects: modest housing and possessions of Soviet characters, war hospital, located in an old mansion.

Means of representation: quasi-realistic, only positive portrayal of Soviet lifestyle.

Characters, their values, ideas; clothes, appearance, lexis, body language: American pilot who voluntary decided to go to the USSR during the war and Soviet citizens with contrasting ideology and social status. All characters are portrayed in a favourable light. Main characters look attractive, especially girls. Their clothes are tasteful. They're optimistic, patriotic, emotional, sometimes expressive gestures, facial expressions and lexis.

A crucial change in characters' life: American pilot John, wounded in battle with Nazis, finds himself in a Soviet hospital, and naturally, falls in love with the beautiful Natasha.

A problem occurred: culture shock, mutual misunderstanding, German troops' attack threat.

Searching for the problem solution: after a series of funny/eccentric situations characters overcome communication and understanding barriers.

Solving the problem: love harmony.

Certainly, the cold war of the second half of the 1940s-1950s crucially changed the orientation of the western screen towards the USSR. However even in 1948 thriller Berlin express the Soviet officer was shown rather with compassion than with suspicion.

A true mass western film attack against the USSR was yet to come...

\section{References:}

1. Bennett, T. (2001). Culture, Power, and Mission to Moscow: Film and Soviet-American Relations during World War II. The Journal of American History, Vol. 88, No. 2, p.495-505.

2. Fedorov, A. (2010). Transformation of the Russian image on the western screen: from ideological confrontation (1946-1991) to modern stage (1992-2010). Moscow: Information for All, 2010. $202 \mathrm{p}$.

3. Lemkhin, M. (2012). Mission to Moscow. www.kinopressa.ru 